\title{
EDITORIAL
}

\section{THE HEALTH OF THE JOURNAL}

New brooms proverbially sweep clean and new editors aim to do likewise. The Journal has a new editor. Some might question the need for any metaphorical clean sweeping or even for any spring cleaning at all. But it must be admitted that the Journal's health and fortunes are not at their rosiest. Oirculation is low and costs are high. Recognition by the medical and scientific press is less than it was or should be. The quantity, and to a lesser extent the quality, of contributions has fallen from what it was in years past.

It is easy but unwise to dogmatize on the role of editorial policy in shaping the fate and fortune of a medical and scientific periodical. In the last analysis a journal can only be as good as the contributions it attracts and prints. Looking back over the 75 years of the Journal's history it can be seen that the halcyon eras have coincided with editorial continuity. Certainly the Journal enjoyed good fortune and high standing during the 32 years from 1908 to 1941 when Sir William Horrocks occupied the editorial chair. His erudite editorial pen did as much to untangle the muddled syntax of his authors as it did to enhance the Journal's reputation. Unfortunately it seems unlikely that a figure of his calibre will ever hold office with such distinction for so long. The Journal-for the foreseeable futurewill have to make do with the somewhat unsatisfactory expedient of amateur editors, each holding office for relatively short tours, but anxious in their own way to sweep clean and make improvements. Too many alleged improvements too often repeated cannot be good for the health of any periodical. For this reason it is prudent to examine critically the changes and improvements suggested now.

First, not perhaps a change but more a reiteration of policy, is the renewed quest for good papers. Seventy-five years ago in the first issue Sir William Taylor ${ }^{1}$ set out the principal objectives for a journal of professional and scientific interest as "1. Original articles written by officers of the Royal Army Medical Corps and others." and "2. Bibliographical notes on articles of importance and interest to the military Services."

These objectives are as true now as they were then. The Journal seeks interesting, clear, concise and lucid reports on original work carried out by serving officers of the Army Medical Services. In addition it should be a journal of record to mark the passage of military and medical milestones, to publish guest lectures of distinction and to report symposia of general and outstanding interest. Unique as the country's only medical journal concerned with the medicine of land warfare it has also an important role in recording military medical history both long past and more recent. A further objective is a thriving correspondence page where professional and scientific controversy may be raised and aired.

More mundane but nevertheless important improvements are planned in the style of the Journal; and perhaps of the presentation as well at a later date. The object of immediate concern is the "Notice to Authors" which now replaces the almost 
time-honoured "Important Notice" on the inside front cover. Any reader who looks at more than one medical journal cannot fail to be struck by the great diversity between them in presentation, style, illustrations and references. Fortunately, there has now been produced by the International Steering Committee of Medical Editors, a body which includes the leading journals on both sides of the Atlantic, an agreement known as the Vancouver Declaration. Fully described in the British Medical Journal', the agreement sets out uniform standards for the presentation of submitted papers. Slowly and in its own small way this Journal will now try to follow suit and adopt what is hoped will become a universal standard. As can be seen from the new notice inside the cover the principal changes concern the setting out of manuscripts, the use of SI units and the numbering of references. Potential authors, especially those whose ink is still wet on their papers, may feel averse to these sudden changes. They need have no fear. Both the old and the new systems will be allowed to co-exist for the next two issues to conplete volume 125. After that, unless the outcry sweeps away new editor and new broom together, the changed order will prevail.

\section{REFERENCES}

1. Taylor, Sir William (1903) L'Envoi. Journal of the Royal Army Medical Corps. 1, 1-4.

2. International Steering Committee of Medical Editors. (1978). Uniform requirements for manuscripts submitted to bio-medical journals. British Medical Journal 1. $1334-1336$.

New Year Honours 1979

CBE Colonel (Now Local Brigadier) $\mathrm{T}$ W A Glenister, Late RAMC (TAVR).

OBE Lieutenant Colonel P J DALY, RAMC (TAVR). Lieutenant Colonel R EYEIONS, RAMC.

MBE Major I M M BAGShaw, RAMC. Major D McL WhitfieLd, RAMC.

ARRC WO1 P R ARTIS, RAMC. Major M E MulHEARn, QARANC.

RRC Colonel M S SHAW, QARANC. 